\title{
Validation and application of an analytical method for the determination of mycotoxins in crackers by UPLC-MS/MS
}

\author{
Bianca Gonçalves MEDINA ${ }^{1}$, André Victor SARTORI ${ }^{1 *}$ (D), Maria Heloísa Paulino de MORAES ${ }^{1}$, \\ Maria Helena Wohlers Morelli CARDOSO ${ }^{1}$, Silvana do Couto JACOB ${ }^{1}$
}

\begin{abstract}
An analytical method applying ultra-performance liquid chromatography-tandem mass spectrometry (UPLC-MS/MS) was validated for the determination of aflatoxins M2, M1, G2, G1, B2, B1, deoxynivalenol, ochratoxin A, fumonisins B1 and B2, hydrolyzed fumonisins B1 and B2, zearalenone and sterigmatocystin in crackers. The obtained recoveries (70 to $110 \%$ ) and relative standard deviations $(<13 \%)$ were considered satisfactory. Method limits of quantification ranged from $0.20 \mu \mathrm{g} \mathrm{kg}^{-1}$ (sterigmatocystin) to $12.27 \mu \mathrm{g} \mathrm{kg}^{-1}$ (deoxynivalenol). The validated method was then applied for mycotoxin determination in 60 cracker samples (cream crackers and water and salt crackers) obtained from the metropolitan area of the state of Rio de Janeiro, RJ. Deoxynivalenol, zearalenone and fumonisin B1 were found, respectively, in 100, 50 and 28\% of the analyzed samples. The maximum permissible limits established by Brazilian legislation for deoxynivalenol and zearalenone were not exceeded in the analyzed samples.
\end{abstract}

Keywords: mycotoxins; UPLC-MS/MS; cracker; wheat-based biscuits.

Practical Applications: A suitable method for routine analysis of mycotoxins in crackers by UPLC-MS/MS was validated. This study reports the results of the first survey on the contamination of crackers in Brazil by aflatoxins M2, M1, G2, G1, B2, B1, deoxynivalenol, ochratoxin A, fumonisins B1 and B2, hydrolyzed fumonisins B1 and B2, zearalenone and sterigmatocystin. The results herein reported suggests that the cracker contamination by deoxynivalenol, zearalenone and fumonisin B1 is an important issue and should be monitored by the Brazilian public health authorities.

\section{Introduction}

Mycotoxins are toxic substances produced naturally as secondary metabolites by several filamentous fungi. These compounds are considered food contaminants, responsible by agriculture and public health problems (International Agency for Research on Cancer, 1993; Peraica et al., 1999; International Agency for Research on Cancer, 2002; Murphy et al., 2006; Zain, 2011; Rocha et al., 2014).

Aflatoxins B1, B2, G1 and G2, deoxynivalenol, fumonisins $\mathrm{B} 1$ and B2, ochratoxin A and zearalenone have been established as the main mycotoxins detected in cereals and cereal-based products and their contamination levels have been regulated in food worldwide (Lee \& Ryu, 2017; Food and Agriculture Organization of the United Nations, 2004; European Commission, 2006a; Brasil, 2011; Brasil, 2017). Other mycotoxins, such as sterigmatocystin (Mol et al., 2016) and hydrolyzed fumonisins (Dombrink-Kurtzman \& Dvorak, 1999), have also been found in these foods. Aflatoxins M1 and M2 can also be produced by fungi, albeit in minor amounts (Bräse et al., 2009; Filazi \& Sireli, 2013) and have been reported in both milk and other foodstuffs, such as cereals (Shotwell et al., 1976; Vesonder et al., 1991; Ren et al., 2007; Huang et al., 2010; Ezekiel et al., 2012; Sartori et al., 2015).
Several mycotoxins, mainly deoxynivalenol and zearalenone, have been reported in wheat and wheat products in several countries (Pussemier et al., 2006; Tanaka et al., 2010; González-Osnaya \& Farrés, 2011; Mishra et al., 2013). In Brazil, a high occurrence of deoxynivalenol in wheat has been described (Lamardo et al., 2006; Santos et al., 2011). However, scarce studies directed to the determination of mycotoxins in wheat products in the country are available (Oliveira et al., 2000; Almeida et al., 2016).

In 2015, Brazil produced 5 to 6 million tons of wheat (Instituto Brasileiro de Geografia e Estatística, 2015) and domestic consumption was of approximately 11 million tons (Empresa Brasileira de Pesquisa Agropecuária, 2015). Wheat is the raw material for the manufacture of many products consumed daily by the population (Almeida et al., 2016). Brazil is the second largest biscuit producer, producing over one million tons in 2013. The per capita consumption of this product in Brazil in 2015 was of $8.47 \mathrm{~kg}$, and crackers were responsible for $21.4 \%$ of this consumption. In 2014, 354 thousand tons of cracker and water and salt crackers were sold, the second most commercialized type of biscuit in Brazil (Associação Brasileira das Indústrias de Biscoitos, Massas Alimentícias e Pães \& Bolos Industrializados, 2015). Crackers are an industrialized product containing $90 \%$ wheat in their formulation (Scudamore et al., 2009). Despite 
the relative importance to consumer health due to the high consumption of this product, only one study has reported contamination by deoxynivalenol in crackers in the country (Souza et al., 2015).

Diverse analytical approaches have been developed aiming at the determination of mycotoxins in food, highlighting the growing application of the liquid chromatography-tandem mass spectrometry (LC-MS/MS) technique in the last years (Krska et al., 2008; Cigić \& Prosen, 2009; Köppen et al., 2010; Ediage et al., 2011; Turner et al., 2009; Turner et al., 2015; Berthiller et al., 2016; Berthiller et al., 2017). The selectivity of this technique has enabled the simultaneous analysis of different mycotoxin classes in different food matrices with only minimum sample treatment (Sulyok et al., 2007; Mol et al., 2016; Chiaradia et al., 2008; Frenich et al., 2009; Lacina et al., 2012).

In this context, the aim of this study was to validate an analytical method suitable for the routine analysis of mycotoxins in crackers by ultra-performance liquid chromatography-tandem mass spectrometry (UPLC-MS/MS). Sample treatment method comprises simultaneous extraction and clean-up (deffating) steps, followed by extract concentration. The analytical method was applied to 60 cracker samples obtained in the metropolitan region of Rio de Janeiro, RJ, Brazil. Additionally, the results were used to estimate population exposure to deoxynivalenol by cracker consumption.

\section{Materials and methods}

\subsection{Reagents and chemicals}

Ammonium formate ( $>99 \%$ ) and formic acid (mass spectrometry grade) were acquired from Sigma-Aldrich (St. Louis, MO, USA), acetonitrile and methanol (HPLC-grade) were obtained from J.T. Baker (Phillipsburg, NJ, USA), while n-Hexane (purity > 96\%), ethyl acetate (for analysis) and potassium hydroxide (pellets for analysis) were obtained from Merck (Darmstadt, Germany). Ultrapure water from a Milli-Q Gradient water system was used (Millipore, Bedford, MA, USA).

\subsection{Standard solutions}

Solid aflatoxin standards, namely B1, B2, G1, G2, M1, M2, ochratoxin A and sterigmatocystin, were purchased from Sigma-Aldrich (St. Louis, MO, USA). Stock ochratoxin A $\left(40 \mu \mathrm{g} \mathrm{mL}^{-1}\right)$ solutions were prepared in toluene/acetic acid $(99: 1, \mathrm{v} / \mathrm{v})$. Individual sterigmatocystin and aflatoxin stock solutions $\left(10 \mu \mathrm{g} \mathrm{mL}^{-1}\right)$ were prepared in acetonitrile. The standard solution concentrations were determined by UV spectrophotometry (Horwitz \& Latimer, 2005), and their stability was verified by UV spectrophotometry at least every twelve months. Stock fumonisin $\mathrm{B} 1$ and $\mathrm{B} 2\left(50 \mu \mathrm{g} \mathrm{mL}^{-1}\right)$ solutions in acetonitrile/water $(1: 1, \mathrm{v} / \mathrm{v})$ and deoxynivalenol in acetonitrile $\left(100 \mu \mathrm{g} \mathrm{mL}^{-1}\right)$ were obtained from Fluka/Sigma-Aldrich (St. Louis, MO, USA). Stock zearalenone solutions in acetonitrile $\left(100.7 \mu \mathrm{g} \mathrm{mL}^{-1}\right)$ were purchased from Biopure (Tulln, Austria). Hydrolyzed fumonisins $\mathrm{B} 1$ and $\mathrm{B} 2$ were prepared by the hydrolysis of fumonisin B1 and B2, according to Dall'Asta et al. (2009). Briefly, $5 \mathrm{~mL}$ of a standard solution containing fumonisin B1 and B2 $\left(50 \mu \mathrm{g} \mathrm{mL}^{-1}\right)$ in acetonitrile/water $(1: 1, \mathrm{v} / \mathrm{v})$ was evaporated to dryness under a nitrogen flow at $40^{\circ} \mathrm{C}$ using a controlled water bath. Residues were dissolved in $5 \mathrm{~mL}$ of a $2 \mathrm{~mol} \mathrm{~L}^{-1} \mathrm{KOH}$ solution and left at room temperature for $12 \mathrm{~h}$. The hydrolyzed fumonisins were then extracted thrice with $10 \mathrm{~mL}$ of ethyl acetate, combined and then again evaporated in the same conditions. The residues were finally dissolved in $5 \mathrm{~mL}$ methanol. No native fumonisins were detected in this final solution by UPLC-MS/MS, indicating that total conversion to the hydrolyzed forms was achieved. Thus, hydrolyzed fumonisin B1 and B2 concentrations in methanol were calculated as 28.1 and $27.6 \mu \mathrm{g} \mathrm{mL}^{-1}$, respectively. All standard solutions were stored at $-18^{\circ} \mathrm{C}$.

\subsection{UPLC-MS/MS analysis}

Liquid chromatography was carried out using an ACQUITY UPLC ${ }^{\mathrm{TM}}$ system (Waters). A BEH C18 column $(100 \mathrm{~mm} \times 2.1 \mathrm{~mm}$ i.d., $1.7 \mu \mathrm{m}$ particle size $)$ maintained at $35^{\circ} \mathrm{C}$ was used as the stationary phase. The mobile phase flow rate was set at $0.3 \mathrm{~mL} \mathrm{~min}^{-1}$. Two elution gradients were used in this study to avoid the presence of fumonisin carryover (Sartori et al., 2017). The aqueous mobile phase of the elution gradient used to determined fumonisins, hydrolyzed fumonisins and sterigmatocystin was $0.3 \%$ acid formic solution, with the gradient beginning at $60 \%$ methanol, increasing to $80 \%$ for $3 \mathrm{~min}$, held at $80 \%$ for $1 \mathrm{~min}$. Following these steps, the system was re-equilibrated with $60 \%$ methanol for $2 \mathrm{~min}$. The aqueous mobile phase of the elution gradient used to determine M2, M1, B2, B1, G2 and G1, ochratoxin A, deoxynivalenol and zearalenon was a $5 \mathrm{mmol} \mathrm{L}^{-1}$ formate ammonium solution, beginning at $10 \%$ methanol, increasing to $100 \%$ during $4 \mathrm{~min}$ and held at $100 \%$ for $1.5 \mathrm{~min}$. The system was then re-equilibrated for 2 min with $10 \%$ methanol. A $5 \mu \mathrm{L}$ injection volume was used for both gradients.

A tandem quadrupole mass spectrometer (Waters, Quattro Premier ${ }^{\mathrm{TM}} \mathrm{XE}$ ) equipped with an electrospray ionization (ESI) source operated in the positive and negative ionization modes was used for analyte detection. The following parameters were set: capillary voltage at $3.5 \mathrm{kV}$, extractor voltage at $3 \mathrm{~V}$, rf lens at $0.1 \mathrm{~V}$, multiplier at $750 \mathrm{~V}$, desolvation temperature at $350^{\circ} \mathrm{C}$ and source temperature at $120^{\circ} \mathrm{C}$. Nitrogen was used both as cone and desolvation gas, at $50 \mathrm{~L} \mathrm{~h}^{-1}$ and $750 \mathrm{~L} \mathrm{~h}^{-1}$, respectively. Argon was applied as the collision gas at $4 \times 10^{-3} \mathrm{mbar}$. The two selected ion transitions $(\mathrm{m} / \mathrm{z})$ for each mycotoxin and their acquisition conditions are presented in Table 1 and 2.

\subsection{Sample preparation}

The method reported by Sartori et al. (2017) was used for sample preparation, as follows. About $3 \mathrm{~g}$ of each sample was weighed in $50 \mathrm{~mL}$ centrifuge tubes, followed by the addition of $5 \mathrm{~mL} \mathrm{n}$-hexane, $5 \mathrm{~mL}$ of a $3 \%$ formic acid solution and $10 \mathrm{~mL}$ acetonitrile. Each tube was vortex-shaken (IKA Works) for $2 \mathrm{~min}$, then sonicated for $10 \mathrm{~min}$ and then centrifuged at 3,000 rpm for $7 \mathrm{~min}$ (Hitach- HIMAC CF 7D2). Subsequently, $5 \mathrm{~mL}$ aliquots of the extracts (acetonitrile/water) was concentrated to dryness as previously described, at $50{ }^{\circ} \mathrm{C}$ in a controlled water bath (Turbo-Vac LV). Finally, residues were dissolved in $1 \mathrm{~mL}$ of methanol/water $(1: 1, \mathrm{v} / \mathrm{v})$ and the resulting solutions were filtered through $0.22 \mu \mathrm{m}$ PVDF membrane filters. After filtration, the solutions were transferred to vial sand taken to the equipment. 
Medina et al.

Table 1. UPLC-MS/MS parameters for fumonisins, hydrolyzed fumonisins and sterigmatocystin.

\begin{tabular}{|c|c|c|c|c|c|c|c|}
\hline Mycotoxins & $\underset{(\min )^{\mathrm{a}}}{\mathrm{t}_{\mathrm{R}}}$ & $\begin{array}{c}\text { Quantifier } \\
\text { transition ion } \\
\mathrm{Q}(m / z)\end{array}$ & $\begin{array}{c}\text { Qualifier } \\
\text { transition ion } \\
\mathrm{q}(\mathrm{m} / z)\end{array}$ & $\mathrm{Q} / \mathrm{q}^{\mathrm{b}}$ & $\begin{array}{c}\text { Energy } \\
\text { collision } \\
(\mathrm{eV})^{\mathrm{c}}\end{array}$ & $\begin{array}{c}\text { Cone voltage } \\
\text { (V) }\end{array}$ & $\begin{array}{c}\text { Dwell time } \\
(\mathrm{s})\end{array}$ \\
\hline Hydrolyzed fumonisin B1 & $1.60(1)$ & $406.3>388.3$ & $406.3>370.3$ & $1.2( \pm 0.2)$ & $20 / 20$ & 30 & 0.05 \\
\hline Hydrolyzed fumonisin B2 & $2.47(2)$ & $390.3>372.3$ & $390.3>354.3$ & $1.3( \pm 0.3)$ & $20 / 20$ & 30 & 0.02 \\
\hline Fumonisin B2 & $2.72(2)$ & $706.2>336.3$ & $706.2>318.3$ & $2.0( \pm 0.4)$ & $35 / 35$ & 50 & 0.02 \\
\hline Sterigmatocystin & $3.00(2)$ & $325.2>281.2$ & $325.2>310.2$ & $1.1( \pm 0.2)$ & $35 / 25$ & 45 & 0.02 \\
\hline
\end{tabular}

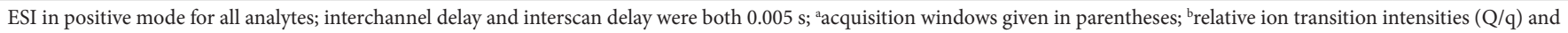

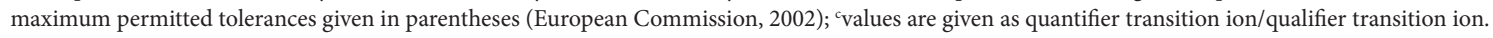

Table 2. UPLC-MS/MS parameters for deoxynivalenol, aflatoxins M2, M1, B2, B1, G2 and G1, ochratoxin A and zearalenone.

\begin{tabular}{|c|c|c|c|c|c|c|c|}
\hline Mycotoxins & $\begin{array}{c}\mathrm{t}_{\mathrm{R}} \\
(\mathrm{min})^{\mathrm{a}}\end{array}$ & $\begin{array}{c}\text { Quantifier } \\
\text { transition ion } \\
\mathrm{Q}(\mathrm{m} / \mathrm{z})\end{array}$ & $\begin{array}{c}\text { Qualifier } \\
\text { transition ion } \\
\mathrm{q}(\mathrm{m} / \mathrm{z})\end{array}$ & $\mathrm{Q} / \mathrm{q}^{\mathrm{b}}$ & $\begin{array}{l}\text { Energy collision } \\
\qquad(\mathrm{eV})^{\mathrm{c}}\end{array}$ & $\begin{array}{c}\text { Cone voltage } \\
\text { (V) }\end{array}$ & $\begin{array}{l}\text { Dwell time } \\
\text { (s) }\end{array}$ \\
\hline Deoxynivalenol & $2.15(1)$ & $297.1>249.1$ & $297.1>231.1$ & $2.2( \pm 0.6)$ & $25 / 25$ & 25 & 0.15 \\
\hline Aflatoxin G2 & $3.04(3)$ & $331.3>245.3$ & $331.3>285.3$ & $1.5( \pm 0.3)$ & $30 / 30$ & 40 & 0.015 \\
\hline Aflatoxin M1 & $3.05(3)$ & $329.2>273.2$ & $329.2>259.2$ & $2.1( \pm 0.5)$ & $25 / 25$ & 50 & 0.015 \\
\hline Aflatoxin B1 & $3.38(3)$ & $313.0>269.2$ & $313.0>285.2$ & $1.8( \pm 0.4)$ & $35 / 25$ & 40 & 0.015 \\
\hline Ochratoxin A & $3.75(4)$ & $404.2>239.2$ & $404.2>358.2$ & $1.6( \pm 0.3)$ & $25 / 15$ & 25 & 0.15 \\
\hline Zearalenone & $4.23(5)$ & $316.9>174.8$ & $316.9>130.8$ & $1.3( \pm 0.3)$ & $25 / 30$ & 50 & 0.15 \\
\hline
\end{tabular}

ESI in positive mode for all analytes, except for zearalenone; Interchannel delay and interscan delay were both $0.005 \mathrm{~s}$; acquisition windows given in parentheses; ${ }^{\mathrm{b}}$ relative ion transition intensities (Q/q) and maximum permitted tolerances given in parentheses (European Commission, 2002); ${ }^{c}$ values are given as quantifier transition ion/qualifier transition ion.

\subsection{Validation}

An analytical method for the determination of aflatoxins M2, M1, G2, G1, B2, B1, deoxynivalenol, ochratoxin A, fumonisins $\mathrm{B} 1$ and $\mathrm{B} 2$, hydrolyzed fumonisins $\mathrm{B} 1$ and $\mathrm{B} 2$, zearalenone and sterigmatocystin in crackers (cream crackers and water and salt crackers) was validated. The following analytical performance parameters were assessed: selectivity, matrix effect, linearity, trueness, precision (repeatability and intermediate precision), limit of detection (LOD) and limit of quantification (LOQ).

The method selectivity was evaluated by analyzing matrix blank samples, to evaluate the presence of interfering signals in all cracker samples.

For the investigation of matrix effects, calibration curves for each compound in each matrix extracts (cream cracker and water and salt cracker) and in methanol/water $(1: 1, \mathrm{v} / \mathrm{v})$ were prepared at six concentration levels, ranging from 0.5 to $25 \mathrm{ng} \mathrm{mL}^{-1}$ (aflatoxins M2, M1, G2, G1, B2, B1 and ochratoxin A and sterigmatocystin), 1 to $100 \mathrm{ng} \mathrm{mL}^{-1}$ (zearalenone), 2.5 to $125 \mathrm{ng} \mathrm{mL}^{-1}$ (hydrolyzed fumonisins $\mathrm{B} 1$ and $\mathrm{B} 2$ ), 1.5 to $75 \mathrm{ng} \mathrm{mL}^{-1}$ (fumonisins $\mathrm{B} 1$ and $\mathrm{B} 2$ ) and 5 to $250 \mathrm{ng} \mathrm{mL}^{-1}$ (deoxynivalenol). The calibration curve slopes were compared by the t-test (Souza, 2007). The effect of sample dilution on the matrix-effect was also evaluated.

Matrix-matched calibration curves at the same concentration levels used to study the matrix effect were used to assess linearity (Souza \& Junqueira, 2005). The homocedasticity, independency and normality of the regression residuals were checked. Outliers were successively investigated by the Jacknife standardised residuals test (Belsley et al., 1980). The homocedasticity of residuals, verified by a modified Levene test (Brown \& Forsythe, 1974) for all the calibration curves was confirmed ( $\mathrm{p}$-values $>0.05$ ). The independency of residuals, verfiied by the Durbin-Watson statistic (Durbin \& Watson, 1951) for all calibration curves was confirmed ( $\mathrm{p}$-values $>0.05$ ). The normality of residuals, checked by the Ryan-Joiner test (Ryan \& Joiner, 1976) for all the calibration curves was confirmed ( $\mathrm{p}$-values $>0.05$ ). The regression significance and the lack-of-fit were performed by an analysis of variance (ANOVA) (Draper \& Smith, 1998).

Method trueness and repeatability were investigated by carrying out recovery studies using cracker samples spiked with the evaluated mycotoxins at three concentration levels, using four replicates for each level. Intermediate precision was assessed by analyzing spiked samples at the same concentrations as the first concentration level, all analyzed within four days, by four different analysts. Repeatability and intermediate precision are expressed by the relative standard deviation (RSD \%), while trueness is expressed by recovery values.

Cracker samples spiked with each investigated compound at the lowest concentration level applied in the recovery studies were used to determine the method limit of detection (LOD) and limit of quantification (LOQ), considering 3 and 10 signal-to-noise ratios, respectively.

\subsection{Cracker biscuit samples}

A total of 60 cracker samples (cream crackers, $\mathrm{n}=30$ and water and salt crackers, $\mathrm{n}=30$ ) were randomly purchased from local supermarkets in the metropolitan region of Rio de Janeiro, 
RJ, Brazil between 2015 and 2016, from 13 different companies, representing 16 different brands. The samples were ground and passed through a $0.84 \mu \mathrm{m}$ sieve and then stored at $-20^{\circ} \mathrm{C}$ until analysis.

\section{Results and discussion}

\subsection{Method validation}

No interfering signals were observed eluting at the same time as the analytes for all studied crackers. Mycotoxins in samples were identified by comparing analyte retention times to standard solution retention times. Confirmation in each sample was obtained by comparison of the signal intensity ratios of the quantifier and qualifier ion transitions of each analyte with those in standard solutions, considering the maximum permissible limits according to the European Union (European Commission, 2002). Figure 1 displays chromatograms of a cracker sample fortified with the investigated mycotoxins. Retention times, ion ratios and the maximum permissible limits for the obtained ion ratios for each assessed mycotoxin are also displayed.

Significant differences ( $\mathrm{p}>0.01)$ were detected between the slopes of the solvent calibration curves and in the matrices for most mycotoxins (except sterigmatocystin in cream crackers and aflatoxins M1 and M2, and hydrolyzed fumonisin B1 in water and salt crackers), demonstrating a significant matrix effect for most of the assessed compounds. Sample dilutions (final extracts) were investigated aiming at reducing or eliminating matrix effects. Sample dilution effects were assessed using two matrix amounts in the final extract $\left(0.1\right.$ and $\left.1 \mathrm{~g} \mathrm{~mL}^{-1}\right)$. Results are displayed in Table 3.
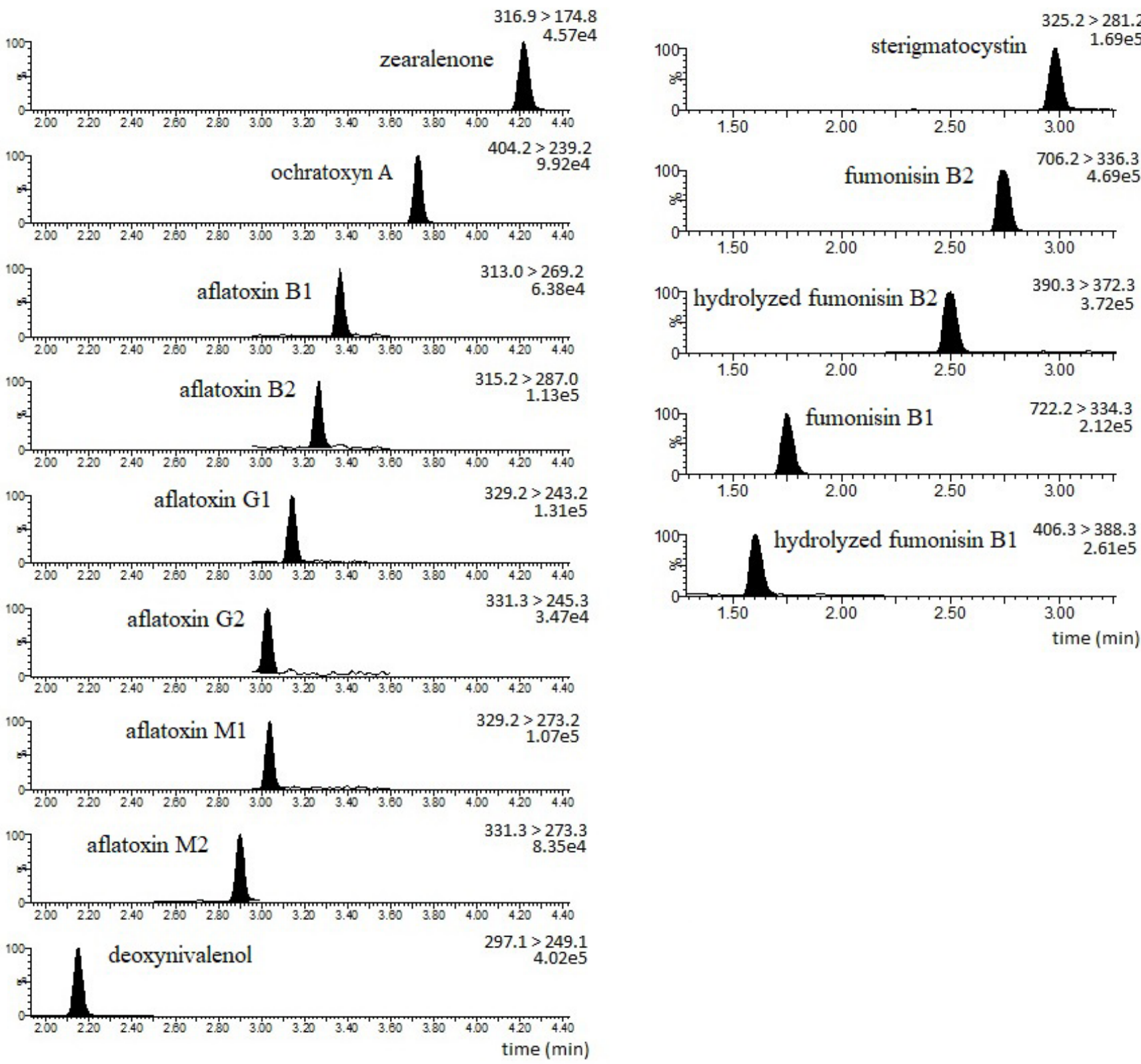

Figure 1. Chromatograms of a cracker sample fortified with the mycotoxins investigated herein. 
A decreased was observed matrix effect for certain mycotoxins with increasing sample dilution. Despite a still significant matrix effect for most mycotoxins, sample dilution was effective in eliminating the matrix effect for deoxynivalenol. For the analytes displaying matrix effects, matrix-match calibrations were used in routine analyses.

Concerning the linearity studies, the following aspects were confirmed for all the calibration curves: homoscedasticity, independency of the residuals, and normality of the residuals ( $p$ values $>0.05$ ). In addition, high regression significance (p-values $<0.001$ ) and non-significant lack-of-fit ( $\mathrm{p}$-values $>0.05$ ) were also noted, attesting curve linearity. Linearity results are displayed in Table 4.
Recovery values ranged from 70 to $110 \%$, with RSD lower than $14 \%$ for all investigated mycotoxins under repeatability conditions. The RSD obtained in the intermediate precision study was always lower than $17 \%$. Thus, results were deemed satisfactory according to Commission Decision 2002/657/EC (European Commission, 2002) and Commission Regulation EC 401/2006 (European Commission, 2006b).

LOD and LOQ values are also displayed in Table 5. Method sensitivity was considered suitable for the routine analysis of the assessed mycotoxins in crackers, in view of the maximum permissible limits for regulated mycotoxins (Brasil, 2011; European Commission, 2006a; Food and Agriculture Organization of the United Nations, 2004).

Table 3. Matrix effects (\%) for the investigated mycotoxins at different extract dilutions.

\begin{tabular}{|c|c|c|c|c|}
\hline \multirow{2}{*}{ Mycotoxins } & \multicolumn{4}{|c|}{ Matrix-effect $(\%)^{a}$} \\
\hline & Cream cracker & Cream cracker (diluted) & Water and salt cracker $^{\mathrm{b}}$ & Water and salt cracker (diluted) \\
\hline Deoxynivalenol & -29.0 & -0.4 & -42.3 & 4.8 \\
\hline Aflatoxin M2 & 4.9 & 0.4 & -4.5 & 3.4 \\
\hline Aflatoxin M1 & 8.1 & -5.3 & -2.4 & 3.3 \\
\hline Aflatoxin G2 & -52.0 & -14.0 & -61.3 & -9.3 \\
\hline Aflatoxin G1 & -57.0 & -12.0 & -66.6 & -15.2 \\
\hline Aflatoxin B2 & -58.2 & -19.2 & -68.8 & -21.7 \\
\hline Aflatoxin B1 & -57.1 & -18.6 & -66.3 & -21.2 \\
\hline Fumonisin B1 & -27.4 & -5.7 & -19.8 & 2.0 \\
\hline Fumonisin B2 & -19.7 & -0.95 & -16.1 & 4.2 \\
\hline Hydrolyzed fumonisin B1 & -26.4 & -5.5 & -13.9 & 6.6 \\
\hline Hydrolyzed fumonisin B2 & -16.4 & 9.5 & -0.2 & 23.9 \\
\hline Ochratoxin A & -24.0 & -1.5 & -43.0 & -0.1 \\
\hline Zearalenone & -42.6 & -9.2 & -58.6 & -7.3 \\
\hline Sterigmatocystin & -4.2 & -4.1 & -7.1 & 9.3 \\
\hline
\end{tabular}

Table 4. Linearity results for the matrix-matched calibrations.

\begin{tabular}{|c|c|c|c|c|c|c|}
\hline \multirow[b]{2}{*}{ Mycotoxins } & \multicolumn{3}{|c|}{ Cream cracker } & \multicolumn{3}{|c|}{ Water and salt cracker } \\
\hline & $\begin{array}{l}\text { Linear range } \\
\left(\mathrm{ng} \mathrm{mL}^{-1}\right)\end{array}$ & Equation & $\mathrm{r}^{2}$ & $\begin{array}{c}\text { Linear range } \\
\left(\text { ng mL }^{-1}\right)\end{array}$ & Equation & $\mathrm{r}^{2}$ \\
\hline Deoxynivalenol & $5-250$ & $y=32.5 x+59.9$ & 0.99 & $5-250$ & $y=26.5 x+116.6$ & 0.99 \\
\hline Aflatoxin M2 & $0.5-20$ & $y=946.6 x+307.2$ & 0.99 & $0.5-25$ & $y=861.2 x-59.0$ & 0.99 \\
\hline Aflatoxin M1 & $0.5-25$ & $y=999.8 x-19.2$ & 0.99 & $0.5-25$ & $y=902.6 x-219.0$ & 0.98 \\
\hline Aflatoxin G2 & $0.5-25$ & $y=391.3 x+79.8$ & 0.99 & $0.5-25$ & $y=316.9 x+4.6$ & 0.98 \\
\hline Aflatoxin G1 & $0.5-25$ & $y=1219.3 x+416.9$ & 0.99 & $0.5-25$ & $y=946.3 x+64.6$ & 0.99 \\
\hline Aflatoxin B2 & $0.5-25$ & $y=1061.1 x+71.3$ & 0.99 & $0.5-25$ & $y=791.3 x+125.5$ & 0.99 \\
\hline Aflatoxin B1 & $0.5-15$ & $y=1448.3 x+745.0$ & 0.99 & $0.5-25$ & $y=1136.9 x+88.9$ & 0.99 \\
\hline Fumonisin B1 & $1.5-45$ & $y=438.5 x+1214.2$ & 0.99 & $1.5-45$ & $y=484.4 x+532.9$ & 0.99 \\
\hline Fumonisin B2 & $1.5-45$ & $y=1084.5 x+2414.6$ & 0.99 & $1.5-45$ & $y=1133.6 x+1081.0$ & 0.99 \\
\hline Hydrolyzed fumonisin B1 & $2.5-125$ & $y=548.0 x+631.1$ & 0.99 & $2.5-125$ & $y=640.8 x-1403.3$ & 0.99 \\
\hline Hydrolyzed fumonisin B2 & $2.5-75.0$ & $y=750.2 x+1867.3$ & 0.99 & $2.5-125$ & $y=895.5 x-1536.6$ & 0.99 \\
\hline Ochratoxin A & $0.5-25$ & $y=598.0 x+189.8$ & 0.99 & $0.5-25$ & $y=449.1 x+120.8$ & 0.99 \\
\hline Zearalenone & $1.0-50$ & $y=1009.1 x+961.6$ & 0.99 & $1.0-50$ & $y=726.9 x+385.9$ & 0.99 \\
\hline Sterigmatocystin & $0.5-25$ & $y=1995.1 x-282.3$ & 0.99 & $0.5-25$ & $y=1933.2 x-174.0$ & 0.99 \\
\hline
\end{tabular}

$r^{2}$ : determination coefficient. 
Table 5. Validation parameters of the analytical method.

\begin{tabular}{|c|c|c|c|c|c|c|c|c|c|}
\hline \multirow{2}{*}{ Mycotoxins } & \multirow{2}{*}{ LOD } & \multirow{2}{*}{ LOQ } & \multicolumn{3}{|c|}{$1 \mu \mathrm{g} \mathrm{kg}^{-1 \mathrm{a}}$} & \multicolumn{2}{|c|}{$5 \mu \mathrm{g} \mathrm{kg}^{-1 \mathrm{a}}$} & \multicolumn{2}{|c|}{$15 \mu \mathrm{g} \mathrm{kg}^{-1 \mathrm{a}}$} \\
\hline & & & $\operatorname{Rec}$ & $\mathrm{RSD}_{\mathrm{r}}$ & $\mathrm{RSD}_{\mathrm{R}}$ & $\operatorname{Rec}$ & $\mathrm{RSD}_{\mathrm{r}}$ & $\operatorname{Rec}$ & $\mathrm{RSD}_{\mathrm{r}}$ \\
\hline Deoxynivalenol & 3.68 & 12.27 & 77.9 & 6.2 & 5.0 & 91.2 & 8.3 & 82.2 & 1.5 \\
\hline Aflatoxin M2 & 0.23 & 0.78 & 76.2 & 3.0 & 7.4 & 109.6 & 9.9 & 84.7 & 4.3 \\
\hline Aflatoxin M1 & 0.40 & 1.33 & 85.3 & 12.2 & 13.3 & 107.6 & 9.0 & 79.0 & 10.2 \\
\hline Aflatoxin G2 & 0.88 & 2.93 & 104.4 & 7.2 & 16.7 & 109.8 & 5.9 & 86.5 & 4.8 \\
\hline Aflatoxin G1 & 0.43 & 1.44 & 70.0 & 3.3 & 3.8 & 91.2 & 8.5 & 78.6 & 2.4 \\
\hline Aflatoxin B2 & 0.41 & 1.38 & 70.3 & 12.3 & 4.0 & 106.7 & 9.1 & 86.3 & 1.8 \\
\hline Aflatoxin B1 & 0.33 & 1.11 & 72.3 & 13.4 & 5.4 & 91.4 & 8.1 & 75.9 & 2.1 \\
\hline Fumonisin B1 & 0.51 & 1.71 & 83.6 & 8.0 & 4.0 & 96.2 & 3.9 & 85.0 & 3.6 \\
\hline Fumonisin B2 & 0.44 & 1.47 & 80.2 & 10.1 & 6.4 & 93.8 & 2.9 & 87.0 & 5.3 \\
\hline Hydrolyzed fumonisin B1 & 2.22 & 7.41 & 71.5 & 11.0 & 8.8 & 91.6 & 2.7 & 77.9 & 5.7 \\
\hline Hydrolyzed Fumonisin B2 & 1.26 & 4.20 & 70.5 & 9.9 & 6.6 & 89.4 & 0.9 & 73.0 & 3.4 \\
\hline Ochratoxin A & 0.09 & 0.31 & 88.0 & 7.6 & 5.1 & 99.5 & 7.3 & 79.3 & 7.9 \\
\hline Zearalenone & 0.68 & 2.25 & 75.6 & 1.9 & 4.6 & 101.0 & 6.2 & 88.7 & 1.3 \\
\hline Sterigmatocystin & 0.06 & 0.20 & 70.9 & 4.9 & 6.3 & 87.0 & 4.1 & 73.9 & 5.5 \\
\hline
\end{tabular}

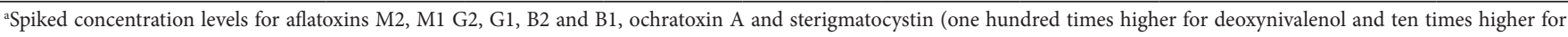
fumonisins and hydrolyzed fumonisins); LOD: Limit of Detection ( $\left.\mu \mathrm{g} \mathrm{kg}^{-1}\right)$; LOQ: Limit of Quantification $\left(\mu \mathrm{g} \mathrm{kg}^{-1}\right)$; Rec: Recovery (\%); RSD $(\%)$ : Relative Standard Deviation (intra-day, $\mathrm{n}=4$ ); $\mathrm{RSD}_{\mathrm{R}}(\%)$ : Relative Standard Deviation (inter-ddayay, $\mathrm{n}=3$ ).

\subsection{Sample analysis}

The validated analytical method was applied for the determination of the 14 target mycotoxins (aflatoxins M2, M1, G1, B2, B1, deoxynivalenol, ochratoxin A, fumonisins B2 and $\mathrm{B} 1$, fumonisins $\mathrm{B} 2$ and $\mathrm{B} 1$ hydrolysates, zearalenone and esterigmatocistin) in 60 cracker samples.

Deoxynivalenol was found in $60(100 \%)$ of the analyzed cracker samples. The mean concentration for the cracker samples was $481.14 \mu \mathrm{g} \mathrm{kg}^{-1}$. In cream cracker samples, concentrations ranging from 66.4 to $1507.4 \mu \mathrm{g} \mathrm{kg}$, were found, with a means of $437.4 \mu \mathrm{g} \mathrm{kg}^{-1}$. Similar levels (between 73.4 and $1444.8 \mu \mathrm{g} \mathrm{kg}^{-1}$, with a mean of $524.9 \mu \mathrm{g} \mathrm{kg}^{-1}$ ) were found in the water and salt cracker samples. The maximum concentration found for deoxynivalenol $\left(1507.4 \mu \mathrm{g} \mathrm{kg}^{-1}\right)$ was lower than the maximum level $\left(5295 \mu \mathrm{g} \mathrm{kg}^{-1}\right)$ found in the study conducted by Souza et al. (2015) with 23 cracker samples from Rio Grande do Sul, Brazil. Compared to studies conducted in other countries evaluating deoxynivalenol contamination, the maximum level found in the present study was higher than the values found by Savi et al. (2016) in crackers (1159 $\left.\mathrm{gg} \mathrm{kg}^{-1}\right)$ and Tanaka et al. (2010) in wheat-based biscuits $\left(791 \mu \mathrm{g} \mathrm{kg}^{-1}\right)$, and similar to the value found by Almeida et al. (2016) in crackers $\left(1720 \mu \mathrm{g} \mathrm{kg}^{-1}\right)$. The incidence of deoxynivalenol in the present study was higher than the $78 \%$ and 30\% reported by Souza et al. (2015) and Savi et al. (2016) and similar to the $98 \%$ found by Tanaka et al. (2010).

Zearalenone was found in 30 (50\%) of the 60 analyzed samples, in concentrations ranging from the LOD tp $14.83 \mu \mathrm{g} \mathrm{kg}^{-1}$, with means of $6.22 \mu \mathrm{g} \mathrm{kg}^{-1}$. Similar levels were found for this mycotoxin in the cream cracker and water and salt crakers, in 13 cream cracker samples (LOD to $13.58 \mu \mathrm{g} \mathrm{kg}^{-1}$ ) and in 17 water and salt crackers samples (LOD to $14.83 \mu \mathrm{g} \mathrm{kg}^{-1}$ ).

In a study carried out by Andrade (2016) in Brasilia, all $14(100 \%)$ analyzed cracker samples were contaminated with zearalenone and the means found was of $560.0 \mu \mathrm{g} \mathrm{kg}^{-1}$, above that found in the present study. In a study carried out in Japan by Tanaka et al. (2010), the levels found are in agreement with those found in the present study, although the incidence of zearalenone-contaminated samples was lower (2\%).

Fumonisin B1 was detected (> LOD) in 17 (28\%) of the analyzed samples, 8 cream cracker and 9 water and salt cracker samples. No studies were found on the presence of fumonisins in crackers, but their presence has been reported in wheat. In the south of Brazil, Mallmann et al. (2001) found fumonisin B1 in one wheat sample. Stankovic et al. (2012) analyzed Serbia wheat samples and found fumonisin B1 in 92 of the 103 analyzed samples, in concentrations ranging from 750 to $5400 \mu \mathrm{g} \mathrm{kg}$. Li et al. (2015) found fumonisin B1 in 22 (6\%) out of 369 wheat flour samples in China, at concentrations ranging between 0.3 and $34.6 \mu \mathrm{g} \mathrm{kg}^{-1}$. The fumonisin contamination found in the samples analyzed herein may be due to the possible presence of corn starch in the samples.

In the present study, four samples showed simultaneous contamination by deoxynivalenol, zearalenone and fumonisin B1. Stankovic et al. (2012) analyzed 103 wheat samples and reported that $47.8 \%$ of the samples contained deoxynivalenol, zearalenone and fumonisin B1, also indicating simultaneous contamination by these compounds.

The concentrations found herein were evaluated according to RDC Resolution No. 07/2011, in force during the sample collection period, that establish the maximum permissible level of 200 and $1750 \mu \mathrm{g} \mathrm{kg}^{-1}$ for zearalenone and deoxynivalenol in crackers, respectively (Brasil, 2011). The results were also evaluated according to RDC No. 138/2017, in effect from January 2017, establishing maximum permissible level of 100 and $1000 \mu \mathrm{g} \mathrm{kg}^{-1}$ for zearalenone and deoxynivalenol in crackers, respectively (Brasil, 2017). No samples exceeded the maximum permissible level according to RDC No. 07/2011 for deoxynivalenol and zearalenone. However, if we consider RDC No. 138/2017, a total of $7(11.7 \%)$ samples would exceed the maximum permissible level for deoxynivalenol. A summary of the results found for the analyzed samples is exhibited in Table 6. 
Table 6. Results found for the samples analyzed in the present study.

\begin{tabular}{|c|c|c|c|c|c|c|c|}
\hline \multirow{2}{*}{ Mycotoxins } & \multirow{2}{*}{$\begin{array}{c}\text { Positive samples } \\
(\%)\end{array}$} & \multicolumn{3}{|c|}{ Cream crackers $\left(\mu \mathrm{g} \mathrm{kg}^{-1}\right)$} & \multicolumn{3}{|c|}{ Water and salt crackers $\left(\mu \mathrm{g} \mathrm{kg}^{-1}\right)$} \\
\hline & & minimum & maximum & average & minimum & maximum & average \\
\hline Deoxynivalenol & $60(100 \%)$ & 66.4 & 1507.4 & 437.4 & 73.4 & 1444.8 & 524.9 \\
\hline Zearalenone & $30(50 \%)$ & $>\mathrm{LOD}$ & 13.58 & 6.64 & $>\mathrm{LOD}$ & 14.83 & 6.38 \\
\hline Fumonisin B1 & $17(28 \%)$ & $>$ LOD & $<$ LOQ & - & $>$ LOD & $<$ LOQ & - \\
\hline
\end{tabular}

LOD: limit of detection; LOQ: limit of quantification.

\subsection{Estimation of deoxynivalenol exposure in cream crackers and water and salt crackers}

The maximum tolerable intake represents the maximum human exposure allowed as a result of the natural occurrence of a certain substance in food, without damaging the health of the individual. To calculate this, the levels established by government agencies should be considered (Souza et al., 2015).

The Brazilian Association of Biscuit Industries estimated that per capita Brazilian consumption of biscuits was of $8.47 \mathrm{~kg}$ in 2015, with the consumption of crackers corresponding to $21 \%$ of this total (Associação Brasileira das Indústrias de Biscoitos, Massas Alimentícias e Pães \& Bolos Industrializados, 2015). Based on these data, cracker consumption was estimated at $4.8 \mathrm{~g}$ per capita per day. Exposure to deoxynivalenol through cracker consumption was then estimated according to previously published studies (Ibáñez-Vea et al., 2011; Pacin et al., 2010). Exposure to deoxynivalenol through crackers was estimated considering that this mycotoxin was present in all samples. The mean amount of deoxynivalenol found in biscuits, of $481 \mu \mathrm{g} \mathrm{kg}^{-1}$, would result in a daily intake of $0.04 \mu \mathrm{g} \mathrm{kg}^{-1}$ of body weight per day considering a $60 \mathrm{~kg}$ adult. This value would not exceed the limit proposed by the JECFA safety authorities (Joint FAO/WHO Expert Committee on Food Additives, 2001), which is of $1.0 \mu \mathrm{g} \mathrm{kg}^{-1}$ body weight per day. Considering the highest concentration found in the analyzed samples ( $\left.1507.4 \mu \mathrm{g} \mathrm{kg}^{-1}\right), 0.12 \mu \mathrm{g} \mathrm{kg}^{-1}$ of body weight per day would be ingested by a $60 \mathrm{~kg}$ person, which would also not exceed the maximum limit allowed. Thus, cracker and salt and water crackers can contribute to $3.8 \%$ of total deoxynivalenol consumption recommended by JECFA.

Souza et al. (2015) and Savi et al. (2016) also estimated deoxynivalenol intake in crackers, which did not exceed the limit recommended by JECFA. In the study carried out by Savi et al., cracker consumption contributed to $3 \%$ of deoxynivalenol ingestion, in agreement with the values observed in the present study. The deoxynivalenol concentrations present in the biscuit samples of this study did not exceed the acceptable value defined by JECFA, but it is worth noting that cracker and salt and water crackers are not the only dietary source of deoxynivalenol, since wheat is present in many other products consumed daily. In addition, the estimated consumption data did not consider a higher daily intake or intake by different age groups.

\section{Conclusions}

An analytical method for the determination of fourteen mycotoxins in crackers by UPLC-MS/MS was validated. The method includes major regulated mycotoxins in wheat-based products (deoxynivalenol and zearalenone). The sample treatment method developed herein is useful for routine analyses, since it involves a simple simultaneous extraction/clean-up step followed by concentration of the obtained extracts. The validated method was applied to the determination of target mycotoxins in 60 cracker samples (cream cracker and water and salt crackers). Deoxynivalenol, zearalenone and fumonisin B1 were found, respectively, in 100, 50 and $28 \%$ of the analyzed samples.

\section{References}

Almeida, A. P., Lamardo, L. C. A., Shundo, L., Silva, S. A., Navas, S. A., Alaburda, J., Ruvieri, V., \& Sabino, M. (2016). Occurrence of deoxynivalenol in wheat flour, instant noodle and biscuits commercialized in Brazil. Food Additives and Contaminants, 9(4), 251-255. http://dx.doi.org/10.1080/19393210.2016.1195880 . PMid:27300261.

Andrade, P. D. (2016). Micotoxinas em cereais e seus produtos: desenvolvimento de método analítico e avaliação do risco da exposição na dieta (Tese de doutorado). Brasília: Universidade de Brasília.

Associação Brasileira das Indústrias de Biscoitos, Massas Alimentícias e Pães \& Bolos Industrializados. (2015). Dados estatísticos. São Paulo: ABIMAPI. Retrieved from http://abimapi.com.br/cloud/ ABIMAPI_ANUARIO_2015.pdf

Belsley, D. A., Kuh, E., \& Welsch, R. E. (1980). Regression diagnostics: identifying influential data and sources of collinearity. New York: John Wiley \& Sons Inc. http://dx.doi.org/10.1002/0471725153.

Berthiller, F., Brera, C., Crews, C., Iha, M. H., Krska, R., Lattanzio, V. M. T., MacDonald, S., Malone, R. J., Maragos, C., Solfrizzo, M., Stroka, J., \& Whitaker, T. B. (2016). Developments in mycotoxin analysis: an update for 2014-2015. World Mycotoxin, 9(1), 5-30. http://dx.doi. org/10.3920/WMJ2015.1998.

Berthiller, F., Brera, C., Iha, M. H., Krska, R., Lattanzio, V. M. T., MacDonald, S., Malone, R. J., Maragos, C., Solfrizzo, M., StranskaZachariasova, M., Stroka, J., \& Tittlemier, S. A. (2017). Developments in mycotoxin analysis: an update for 2015-2016. World Mycotoxin, 10(1), 5-29. http://dx.doi.org/10.3920/WMJ2016.2138.

Bräse, S., Encinas, A., Keck, J., \& Nising, C. F. (2009). chemistry and biology of mycotoxins and related fungal metabolites. Chemical Reviews, 109(9), 3903-3990. http://dx.doi.org/10.1021/cr050001f. PMid:19534495.

Brasil, Ministério da Saúde, Agência Nacional de Vigilância Sanitária. (2011, fevereiro 18). Resolução RDC n 7, de 18 de fevereiro de 2011. Dispõe sobre limites máximos tolerados (LMT) para micotoxinas em alimentos. Diário Oficial da União.

Brasil, Ministério da Saúde, Agência Nacional de Vigilância Sanitária. (2017, fevereiro 8). Resolução RDC n 138, de 8 de fevereiro de 2017. Dispõe sobre limites máximos tolerados (LMT) para micotoxinas em alimentos, para alterar os LMT da micotoxina desoxinivalenol (DON) em trigo e produtos de trigo prontos para oferta ao consumidor e os prazos para sua aplicação. Diário Oficial da União. 
Brown, B. M., \& Forsythe, A. B. (1974). Robust tests for the equality of variances. Journal of the American Statistical Association, 69(346), 364-367. http://dx.doi.org/10.1080/01621459.1974.10482955.

Chiaradia, M. C., Collins, C. H., \& Jardim, I. C. S. F. (2008). O estado da arte da cromatografia associada à espectrometria de massas acoplada à espectrometria de massas na análise de compostos tóxicos em alimentos. Quimica Nova, 31(3), 623-636. http://dx.doi. org/10.1590/S0100-40422008000300030.

Cigić, I. K., \& Prosen, H. (2009). An overview of conventional and emerging analytical methods for the determination of mycotoxins. International Journal of Molecular Sciences, 10(1), 62-115. http:// dx.doi.org/10.3390/ijms10010062. PMid:19333436.

Dall'Asta, C., Mangia, M., Berthiller, F., Molinelli, A., Sulyok, M., Schuhmacher, R., Krska, R., Galaverna, G., Dossena, A., \& Marchelli, R. (2009). Difficulties in fumonisin determination: the issue of hidden fumonisins. Analytical and Bioanalytical Chemistry, 395(5), 13351345. http://dx.doi.org/10.1007/s00216-009-2933-3. PMid:19588126.

Dombrink-Kurtzman, M. A., \& Dvorak, T. J. (1999). Fumonisin content in masa and tortillas from Mexico. Journal of Agricultural and Food Chemistry, 47(2), 622-627. http://dx.doi.org/10.1021/jf9807162. PMid:10563942.

Draper, N., \& Smith, H. (1998). Applied regression analysis. New York: Wiley. http://dx.doi.org/10.1002/9781118625590.

Durbin, J., \& Watson, G. S. (1951). Testing for serial correlation in least squares regression ii. Biometrika, 38(159), 1-2, 159-178. http://dx.doi. org/10.1093/biomet/38.1-2.159. PMid:14848121.

Ediage, E. N., Mavungu, J. D., Monbaliu, S., Van Peteghem, C., \& Saeger, S. (2011). Validated Multianalyte LC-MS/MS Method for Quantification OF 25 Mycotoxins in Cassava Flour, Peanut Cake and Maize Samples. Journal of Agricultural and Food Chemistry, 59(10), 5173-5180. http://dx.doi.org/10.1021/jf2009364. PMid:21495720.

Empresa Brasileira de Pesquisa Agropecuária - EMBRAPA. (2015). 2014 - Estatística - Trigo em números. Passo Fundo: Embrapa. Retrieved from http://www.cnpt.embrapa.br/pesquisa/economia/2014_01_ TRIGO\%20em\%20numeros.pdf

European Commission. (2002). Commission decision 2002/657/EC of 12 August 2002. Implementing Council Directive 96/23/EC concerning performance of analytical methods and the interpretation of results. Official Journal of the European Communities.

European Commission. (2006a). Setting maximum levels for certain contaminants in foodstuffs. Commission Regulation (EC) No 1881/2006. Official Journal of the European Union.

European Commission. (2006b). Commission Regulation (EC) No. $401 / 2006$. Laying down the methods of sampling and analysis for the official control of the levels of mycotoxins in foodstuffs. Official Journal of the European Union.

Ezekiel, C. N., Sulyok, M., Warth, B., Odebode, A. C., \& Krska, R. (2012). Natural occurrence of mycotoxins in peanut cake from Nigeria. Food Control, 27(2), 338-342. http://dx.doi.org/10.1016/j. foodcont.2012.04.010.

Filazi, A., \& Sireli, U. T. (2013). Occurrence of aflatoxins in food, aflatoxins - recent advances and future prospects. London: InTech. Retrieved from http://www.intechopen.com/books/aflatoxins-recentadvances-and-future-prospects/occurrence-of-aflatoxins-in-food

Food and Agriculture Organization of the United Nations - FAO. (2004). Worldwide regulations for mycotoxins in food and feed in 2003. Rome: FAO Food and Nutrition.

Frenich, A. G., Vidal, J. L. M., Romero-González, R., \& AguileraLuiz, M. M. (2009). Simple and high-throughput method for the multimycotoxin analysis in cereals and related foods by ultra-high performance liquid chromatography/tandem mass spectrometry. Food Chemistry, 117(4), 705-712. http://dx.doi.org/10.1016/j. foodchem.2009.04.045.

González-Osnaya, L., \& Farrés, A. (2011). Deoxynivalenol and zearalenone in Fusarium-contaminated wheat in México City. Food Additives and Contaminants, 4(1), 71-78. http://dx.doi.org/10.1080/1939321 0.2011.551944. PMid:24779666.

Horwitz, W., \& Latimer, G. W. (2005). Official Methods of Analysis of AOAC International, eighteenth ed. AOAC, Gaithersburg.

Huang, B., Han, Z., Cai, Z., Wu, Y., \& Ren, Y. (2010). Simultaneous determination of aflatoxins B1, B2, G1, G2, M1 and M2 in peanuts and their derivative products by ultra-high-performance liquid chromatography-tandem mass spectrometry. Analytica Chimica Acta, 662(1), 62-68. http://dx.doi.org/10.1016/j.aca.2010.01.002. PMid:20152266.

Ibáñez-Vea, M. I., Lizarraga, E., Gonzalez-Penas, E., \& Cerain, A. L. (2011). Simultaneous determination of type-A and type-B trichothecenes in barley samples by GC-MS. Food Control, 22(8), 1428-1434. http:// dx.doi.org/10.1016/j.foodcont.2011.03.004.

Instituto Brasileiro de Geografia e Estatística. (2015). Rio de Janeiro: IBGE. Retrieved from http://www.ibge.gov.br/home/estatistica/ indicadores/agropecuaria/lspa/lspa_2015.pdf

International Agency for Research on Cancer. (1993). Evaluation of carcinogen risks to humans. Some naturally occurring substances: foods items and constituents, heterocyclic aromatic amines and mycotoxins. IARC Monographs on the Evaluation of Carcinogenic Risks to Humans, 56, 489-521. PMid:8411629.

International Agency for Research on Cancer. (2002). Some traditional herbal medicines, some mycotoxins, naphthalene and styrene. IARC Monographs on the evaluation of carcinogenic risks to humans. IARC Monographs, 82, 301-366.

Joint FAO/WHO Expert Committee on Food Additives - JECFA. (2001). Safety evaluation of certain mycotoxins in food. In 56th Meeting of the JECFA (WHO Food Additives Series, no. 47; Food and Nutrition Paper 74, pp. 419-555). Rome: JECFA.

Köppen, R., Koch, M., Siegel, D., Merkel, S., Maul, R., \& Nehls, I. (2010). Determination of mycotoxins in foods: current state of analytical methods and limitations. Applied Microbiology and Biotechnology, 86(6), 1595-1612. http://dx.doi.org/10.1007/s00253-010-2535-1. PMid:20339844.

Krska, R., Schubert-Ullrich, P., Molinelli, A., Sulyok, M., Macdonald, S., \& Crews, C. (2008). Mycotoxin analysis: an update. Food Additives and Contaminants, 25(2), 152-163. http://dx.doi. org/10.1080/02652030701765723. PMid:18286405.

Lacina, O., Zachariasova, M., Urbanova, J., Vaclavikova, M., Cajka, T., \& Hajslova, J. (2012). Critical assessment of extraction methods for the simultaneous determination of pesticide residues and mycotoxins in fruits, cereals, spices and oil seeds employing ultra-high performance liquid chromatography-tandem mass spectrometry. Journal of Chromatography A, 1262, 8-18. http://dx.doi.org/10.1016/j. chroma.2012.08.097. PMid:23010246.

Lamardo, L. C. A., Navas, S. A., \& Sabino, M. (2006). Desoxinivalenol (DON) em trigo e farinha de trigo comercializados na cidade de São Paulo. Revista do Instituto Adolfo Lutz, 65(1), 32-35.

Lee, H. J., \& Ryu, D. (2017). Worldwide occurrence of mycotoxins in cereals and cereal-derived food products: public health perspectives of their co-occurrence. Journal of Agricultural and Food Chemistry, 65(33), 7034-7051. http://dx.doi.org/10.1021/acs.jafc.6b04847. PMid:27976878. 
Li, F., Jiang, D., Zheng, F., Chen, J., \& Li, W. (2015). Fumonisins B1, B2 and B3 in corn products, wheat flour and corn oil marketed in Shandong province of China. Food Additives and Contaminants, 8(3), 169-174. http://dx.doi.org/10.1080/19393210.2015.1028480 . PMid:25777369.

Mallmann, C. A., Santurio, J. M., Almeida, C. A. A., \& Dilkin, P. (2001). Fumonisin B1 levels in cereals and feeds from Southern Brazil. Arquivos do Instituto Biológico, 68(1), 41-45.

Mishra, S., Ansari, M. K., Dwivedi, D. P., Pandey, P. H., \& Das, M. (2013). Occurrence of deoxynivalenol in cereals and exposure risk assessment in Indian population. Food Control, 30(2), 549-555. http://dx.doi.org/10.1016/j.foodcont.2012.07.041.

Mol, H. G. J., MacDonald, S. J., Anagnostopoulos, C., Spanjer, M., Bertuzzi, T., \& Pietri, A. (2016). European survey on sterigmatocystin in cereals, cereals-based products, beer and nuts. World Mycotoxin Journal, 9(4), 633-642. http://dx.doi.org/10.3920/WMJ2016.2062.

Murphy, P. A., Hendrich, S., Landgren, C., \& Bryant, C. M. (2006). Food mycotoxins: an update. Journal of Food Science, 71(5), 51-65. http://dx.doi.org/10.1111/j.1750-3841.2006.00052.x.

Oliveira, Q., Soares, L. M. V., \& Sawazaki, E. (2000). Levantamento da incidência de desoxinivalenol, diacetoxiscirpenol e toxina T2 em híbridos de milho pipoca plantados no Estado de São Paulo e em milho pipoca comercializado na Cidade de Campinas, SP. Food Science and Technology (Campinas), 21(3), 330-333. http://dx.doi. org/10.1590/S0101-20612001000300014.

Pacin, A., Bovier, E. C., Cano, G., Taglieri, D., \& Pezzani, C. H. (2010). Effect of the bread making process on wheat flour contaminated by the deoxynivalenol and exposure estimate. Food Control, 21(4), 492-495. http://dx.doi.org/10.1016/j.foodcont.2009.07.012.

Peraica, M., Radic, B., Lucic, A., \& Pavlovic, M. (1999). Toxic effects of mycotoxins in humans. Bulletin of the World Health Organization, 77(9), 754-766. PMid:10534900.

Pussemier, L., Piérard, J. Y., Anselme, M., Tangni, E. K., Motte, J. C., \& Larondelle, Y. (2006). Development and application of analytical methods for the determination of mycotoxins in organic and conventional wheat. Food Additives and Contaminants, 23(11), 12081218. http://dx.doi.org/10.1080/02652030600699312. PMid:17071524.

Ren, Y., Zhang, Y., Shao, S., Cai, Z., Feng, L., Pan, H., \& Wang, Z. (2007). Simultaneous determination of multi-component mycotoxin contaminants in foods and feeds by ultra-performance liquid chromatography tandem mass spectrometry. Journal of Chromatography. A, 1143(1-2), 48-64. http://dx.doi.org/10.1016/j. chroma.2006.12.064. PMid:17234198.

Rocha, M. E. B., Freire, F. C. O., Maia, F. E. F., Guedes, M. I. F., \& Rondina, D. (2014). Mycotoxins and their effects on human and animal health. Food Control, 36(1), 159-165. http://dx.doi.org/10.1016/j. foodcont.2013.08.021.

Ryan, T. A., \& Joiner, B. L. (1976). Normal probability plots and tests for normality. The State College: Pennsylvania State University.

Santos, J. S., Oliveira, T. M., Martins, L. M., Hashimoto, E. H., Bassoi, M. C., Pires, J. L. F., Miranda, M. Z., Garcia, S., Itano, E. N., Ono, E. Y. S., Kawamura, O., \& Hirooka, E. Y. (2011). Monitoramento e nível de ingestão de desoxinivalenol por trigo. Semina Ciências Agrárias, 32(4), 1439-1450. http://dx.doi.org/10.5433/1679-0359.2011v32n4p1439.

Sartori, A. V., Mattos, J. S., Souza, Y. P., Santos, R. P., Moraes, M. H. P., \& Nóbrega, A. W. (2015). Determination of aflatoxins M1, M2, B1, B2, G1 and G2 in peanut by modified QuEChERS method and ultra-high performance liquid chromatography-tandem mass spectrometry. Revista Visa em Debate, 3, 115-121.
Sartori, A. V., Moraes, M. H. P., Santos, R. P., Souza, Y. P., \& Nóbrega, A. W. (2017). Determination of mycotoxins in cereal-based porridge destined for infant consumption by ultra-high performance liquid chromatography-tandem mass spectrometry. Food Analytical Methods, 10(12), 4049-4061. http://dx.doi.org/10.1007/s12161-017-0965-4.

Savi, G. D., Piacentini, K. C., Tibola, C. S., Santos, K., Maria, G. S., \& Scussel, V. M. (2016). Deoxynivalenol in the wheat milling process and wheat-based products and daily intake estimates for the Southern Brazilian population. Food Control, 62, 231-236. http://dx.doi. org/10.1016/j.foodcont.2015.10.029.

Scudamore, K. A., Hazel, C. M., Patel, S., \& Scriven, F. (2009). Deoxynivalenol and other Fusarium mycotoxins in bread, cake, and biscuits produced from UK-grown wheat under commercial and pilot scale conditions. Food Additives and Contaminants, 26(8), 1191-1198. http://dx.doi.org/10.1080/02652030902919426.

Shotwell, O. L., Goulden, M. L., \& Hesseltine, C. W. (1976). Aflatoxin M1. Occurrence in stored and freshly harvested corn. Journal of Agricultural and Food Chemistry, 24(3), 683-684. http://dx.doi. org/10.1021/jf60205a018. PMid:818145.

Souza, S. V. C. (2007). Procedimento para validacão intralaboratorial de métodos de ensaio: delineamento e aplicabilidade em análise de alimentos (Tese de doutorado). Universidade Federal de Minas Gerais, Belo Horizonte.

Souza, S. V. C., \& Junqueira, R. G. (2005). A procedure to assess linearity by ordinary least squares method. Analytica Chimica Acta, 552(1-2), 25-35. http://dx.doi.org/10.1016/j.aca.2005.07.043.

Souza, T. D., Caldas, S. S., Primel, E. G., \& Furlong, E. B. (2015). Exposure to deoxynivalenol, Ht-2 and T-2 toxins by consumption of wheat-based product in southern Brazil. Food Control, 50, 789793. http://dx.doi.org/10.1016/j.foodcont.2014.10.015.

Stankovic, S., Levic, J., Ivanovic, D., Krnjaja, V., Stankovic, G., \& Tancic, S. (2012). Fumonisin B1 and its co-occurrence with other fusariotoxins in naturally-contaminated wheat grain. Food Control, 23(2), 384-388. http://dx.doi.org/10.1016/j.foodcont.2011.08.003.

Sulyok, M., Krska, R., \& Schuhmacher, R. A. (2007). Liquid chromatography/ tandem mass spectrometric multi-mycotoxin method for the quantification of 87 analytes and its application to semi-quantitative screening of moldy food samples. Analytical and Bioanalytical Chemistry, 389(5), 1505-1523. http://dx.doi.org/10.1007/ s00216-007-1542-2. PMid:17874237.

Tanaka, H., Sugita-Konishi, Y., Takino, M., Tanaka, T., Toriba, A., \& Hayakawa, K. (2010). A survey of the occurrence of Fusarium mycotoxins in biscuits in Japan by using LC/MS. Journal of Health Science, 56(2), 188-194. http://dx.doi.org/10.1248/jhs.56.188.

Turner, N. W., Bramhmbhatt, H., Szabo-Vezse, M., Poma, A., Coker, R., \& Piletsky, S. A. (2015). Analytical methods for determination of mycotoxins: an update (2009-2014). Analytica Chimica Acta, 901, 12-33. http://dx.doi.org/10.1016/j.aca.2015.10.013. PMid:26614054.

Turner, N. W., Subrahmanyam, S., \& Piletsky, S. A. (2009). Analytical methods for determination of mycotoxins: a review. Analytica Chimica Acta, 632(2), 168-180. http://dx.doi.org/10.1016/j.aca.2008.11.010. PMid:19110091.

Vesonder, R., Haliburton, J., Stubblefield, R., Gilmore, W., \& Peterson, S. (1991). Aspergillus flavus and aflatoxins B1, B2, and M1 in corn associated with equine death. Archives of Environmental Contamination and Toxicology, 20(1), 151-153. http://dx.doi.org/10.1007/BF01065342. PMid:1670319.

Zain, M. E. (2011). Impact of mycotoxins on humans and animals. Journal of Saudi Chemical Society, 15(2), 129-144. http://dx.doi. org/10.1016/j.jscs.2010.06.006. 